\title{
LINGUISTIC REALITIES IN KENYA: A PRELIMINARY SURVEY
}

\author{
Amitabh Vikram Dwivedi
}

\begin{abstract}
The present paper investigates the linguistic realities of Kenya. In this multilingual country every language is not equal in status. Broadly, there are three language groups in Kenya, namely Bantu, Nilotic and Cushitic, and each group includes more than five languages which makes Kenya as a multilingual country with about forty-two languages. Kiswahili, an indigenous language, is a national language of Kenya, and it is mainly used in schools and universities along with English as a medium of instruction. Under linguistic hegemony minor and lesser known languages have often been neglected inside and outside the country. However, they have been serving as a marker of identity amongst the ethnic community in the country. The linguistic diversity in Kenya is a boon for a field linguist but misinformed politicians and education policy makers are deliberately forgetting this language heritage. This paper will not only discuss the challenges that these languages are facing but also give suggestions to revive the linguistic culture in the country.

Keywords: linguistic realities; language groups; linguistic diversity; language heritage.
\end{abstract}

http://dx.doi.org/10.4314/gjl.v3i2.2

\section{Introduction}

The paper examines the languages and language realities of Kenya from colonialism to date. Language realities have been observed in this study from a temporal lens of past, present and future with a focus on indigenous languages that have now become less important politically, and consequently are reduced to the status of either minority or endangered languages, such as Terik, El Molo, Ogiek, Omotik, Bong'om, Sogoo, Suba and Yaaku. Some of them have become extinct due to linguistic favouritism of the dominant languages as well as socio-economic reasons.

Broadly, there are three language groups in Kenya, namely Bantu which includes Kiswahili, Gikuyu, EkeGusii, Luhya and Kamba; examples of Nilotic languages are Kalenjin, Luo, Turkana and Maasai, and Cushitic includes Rendile, Somali Borana 
and Gabra. Each group includes more than five dialects, which makes Kenya a multilingual country with nearly forty-two languages.

Kiswahili, an indigenous language, is an endo-glossic national language of Kenya. It is mainly used for government administration and in schools and universities along with English as a medium of instruction. English, an exo-glossic language, is largely used in government and diplomacy. Under linguistic hegemony minor and lesser known languages have been often neglected inside and outside the country, however, they have been serving as markers of identity amongst the ethnic communities in the country.

The linguistic diversity in Kenya is a boon for a field linguist but misinformed politicians and education policy makers are deliberately forgetting this language heritage. This paper will not only discuss the challenges that these languages are facing but also provide suggestions to revive the linguistic culture in the country.

\section{Historical Background and Discussion}

The Berlin-Congo Conference of 1884-1885 divided the African continent and birthed the geography of Kenya and other African nations. In 1920, Kenya became a colony, controlled by the then British East Africa. The new rulers employed four C's (Commerce, Conquest, Christianity and Civilization (Bos, 2002)), the English language and education policies to govern the newly established protectorate. Since then the education and language policy has been a dilemma for the ruling government. This dilemma has been largely reflected and supported by the fact that any administrator (British or Kenyan) could not stick to a uniform language policy which would rightly justify the cause for the language selection in the education system. The missionaries wanted to spread Christianity in the region (Mazrui \& Mazrui 1999), and the colonizers were interested in low grade assistants and helpers who could understand and follow their commands. Hence, the European colonization and evangelism were in unison initially for English language as a medium of communication rather than any other indigenous languages for Kenya. The colonial government promoted English language which later on influenced the post-colonial language policies, and linguistic attitudes of the people from the elite backgrounds.

The earliest missionaries-cum-educationalists, e.g. Rev. Krapf, Bishop Steere, and Father Sacleux in United Missionary Conference in 1909 recommended biased bilingual education policies in the nation where English was adopted from intermediate to advance level, and the mother tongues and Kiswahili for the first 
three classes and two of middle classes in the primary level respectively (Gorman 1974).

The colonial administration was reluctant to teach English to the colonized population at an early stage. Mazrui \& Mazrui (1996) suggested that the colonizers never wanted the native people of Kenya to achieve proficiency and competency in English as they thought that "social distance between master and subject had to be maintained partly through linguistic distance" (Mazrui 1996: 272). It is well supported by the Critical Period Hypothesis (Jedynak 2009) that the ability to acquire language is biologically linked to age, i.e. if the speakers do not acquire English at an early age they will not be able to achieve native-like proficiency. The biased thinking of the early policy makers is also reflected in Phelps-Stokes Commission of 1924, in its recommendation to drop Kiswahili in upper primary level and to make the people linguistically challenged and dependent upon a non-native tongue.

The post-World War II period again witnessed a change in the education policy of the colonizers. This time, they wanted to create a few English-speaking elites to support their hegemony. Following the reports of Beecher (1949), Binn (1952) and the Drogheda Commission (19520, the three languages formula was dropped, and consequently Kiswahili was dropped too from the curriculum; and mother tongue and English were introduced in the lower primary level in 1953-55. Chimerah (1998) and Mazrui \& Mazrui (1998) have pointed out that Kiswahili was dropped out from the education system because it was mobilizing people in the freedom struggle. Further, Prator-Hutasoit Commission supported only English in the country at all levels. These dividing language tendencies introduced a clear cleft between the language of the elite (using dominant English language) and the masses (using minor and indigenous native languages). The main motive of the British educationalists was to curb Kenyan nationalism. This rift initiated a serious contestation and mediation on the question of selection of a lingua franca of the nation. Within a year after independence in 1964, the colonial based structures were adopted by the indigenous educationalists in their language policies, and Kenya Education Commission took initiatives to establish a three language formula in school education. Since Kiswahili was able to serve as many of its speakers as possible, and no single ethnic group claimed its ownership, Kiswahili was included in the curriculum for the purpose of regional and national unity, and the Ominde Commission recommended English from the initial classes to the advance level. In 1981, the Mackay Commission made Kiswahili a compulsory subject at both primary and secondary level, and English became the medium of instruction. It also suggested the use of mother tongue at lower levels. 
Many writers, for example, Ngugi wa Thiong'o, a renowned scholar from Kenya, adopted linguistic techniques, such as language switching, linguistic shifting, codeswitching, code-mixing, using argots and indigenous language alike to show their support. Thiong'o also advocated the teaching of African literatures by using African languages so that children and youth would know their historical past. Though the writers like Henry Kuria, Gerishon Ngugi, etc. produced creative writings in the native languages, yet the standardization of Kiswahili proved to be a block to the growth of indigenous languages. In a multilingual nation, when some languages are supported and promoted by the ruling government, they become dominant while the future of other minor languages becomes bleak. Consequently, Kiswahili enjoyed dominance, along with English, over other minor languages.

The knowledge of a language of international currency is not a curse, and it is always required in a country of approximately forty languages to promote inter-ethnic communication. But the colonial mind-sets of the people worked against the growth of regional and indigenous languages. Many children from elite backgrounds did not get language input in their mother-tongues, as a result they picked up English first, from their parents and peers. Moreover, corporal punishment for using mother tongues in the school, and other monetary and humiliating treatments for not using English were common practices which had been filling native minds with revulsion for their own tongues (Ngugi 1978).

The situation of English, Kiswahili and other indigenous languages in Kenya is similar to English, Hindi, and other Indian languages in India. The supremacy of English has been prevailing at the cost of other languages. I remember that in my school days in India I was charged one rupee Indian currency fine for using Hindi (my mother tongue) in school, which was followed by minor punishments. But in India, English has been accepted as a lingua franca and its use has not become associated with anti-nationalist tendencies as in Kenya.

Kiswahili, a co-official language and a language spoken by the majority of the people, enjoys a near equal status with English. However, the emergence of language varieties like 'Sheng' has been posing a challenge for Kiswahili. Recently, English and Kiswahili have suffered a blow from this language which is used by mostly young adults and pre-adolescents as a symbol of group identity. This emerging language is a mixture of English, Kiswahili, and words from other ethnic languages that was initially used in the slum areas of Eastlands of Nairobi (Momanyi 2009). 
But the real danger is for unwritten indigenous languages, for which there is no sign of standardization or respect. Their exclusion and segregation from an obtuse reason, their speakers' not being able to pronounce certain phonemes differently: [sh] and [s] or [ph] and [f] or [w] and [v] are sounded alike (Kahraman, 2012). The true imitators (their imitations have neither transformed the imitator-self nor the imitated-object) always advocate the currency of speaking properly rather than the manipulative power of the speakers. The bottom line is, if their pronunciations of English or Kiswahili are influenced by their mother tongues then they cannot be included in the elite class.

Another instance of how language marks similar identity and differentiates among ethnic groups is stated by Ogechi: "In times of crisis such as 1992, 1997, 2002 and 2007-8 during the ethnic clashes ... the Mungiki adherents stopped trucks that had ferried the KANU supporters to Nyeri and greeted them in Gikuyu - 'Thaai!' (spiritual leader). Those who responded were spared while those who could not were butchered (Ogechi 2003). This form of imitation might soon transform an independent nation into a dependent nation depending on the legacy of the colonized culture. Despite the fact that English is spoken by few it proudly entertains the status of prestige language of the elite class in the country. The mediation and contestation against linguistic imperialism has been often blamed by the administration and elites as a reason for the declining standards of these two official languages (Nabea 2009: 128).

Post-independence, a linguistic struggle started, and it can be said that indigenous minor languages once again demanded self-determination. New ways were adopted to promote native languages and to negate the hegemony of English. Ashcroft et al (2002) suggested that abrogation, appropriation, and patois were extensively employed by literary writers in their work. The writers started to write in their own cultures and languages. The most notable example is Gerishon Ngugi's work on Gikuyu and the Kikuyu ethnic community. But whether the popular novels and bestsellers among the peasants and clansmen are changing the mind-set of the population at large is a worthy question, when the language in dominance and power in the past, i.e. English, still opens new horizons for employment. And we should not be blinded by the fact that the popular writers writing in a vernacular have been also translating their work into other popular languages including English. The legacy of colonial control is hard to break; even though Kenya is independent and the languages of the nations may flourish evenly, yet this imbalanced promotion of languages in the nation clearly indicates that they were prevented from becoming what they might have become. 
On the other side of the coin, code-mixing and code-switching have been helping the speakers to domesticate both the languages and facilitating the communication of the speakers. This also shows the resilient and transformative nature of Kenyan culture, and prevents us from focussing on mere victimization and exploitation. Nabea (2009) gives the example of Meru, a Bantu language, which has largely borrowed from English and Kiswahili to develop a mixed vocabulary. In a way, it proves that this indigenous language has a capacity to include new words in its vocabulary according to the requirements of the speakers; at the same time it also alarms us that too much contact and linguistic borrowing might make the speakers of Meru believe that it is a dialect of a standard language. Moreover, this will also result in breaking the conventional grammatical rules of the language by the speakers. Furthermore, it is believed that incorrect usage should not be ignored on its face value, and it should be treated as an example of a challenge to dominant languages (Street 1993, Pardoe 2000). This is at least not so a compromising state than if the children were no longer acquiring their mother tongues.

\section{Conclusion}

Presently, language endangerment is a serious threat to many indigenous languages of Kenya. The external forces and subjugation, chiefly economic, linguistic, cultural, education, and military; internal forces and negative attitudes, unemployment, discrimination, low self-esteem, hesitation, etc. have been causing danger to the existence of many a minority language. Bilingualism, socio-economic disadvantage, prevalence of negative attitudes and non-transmission of minor languages are the indicators that language is highly endangered (Batibo 2005).

Many social scientists and scholars might raise an eyebrow concerning the importance of saving languages when other significant issues, like poverty, corruption, terrorism, racism, molestation, unemployment, diseases etc. are rampant. But language transfers culture, it establishes identity, and it socializes the human being. The engagement and sharing with the dominant colonial language has been influencing and transforming the indigenous languages at large. And when language dies; culture dies. If the last speaker of a language dies what benefit will any record, either electronic or on paper, provide to the growth of the language? So we cannot plainly rely on extensive language documentation without motivating the speakers to pass the language to the new generation.

Education institutions generally have a desire to make their citizens powerful and self-sufficient. But it should not be on the cost of minority languages. Mono- 
lingualism and bi-lingualism should be replaced by an active multilingualism, because it is important for education policy and research, for teacher education, material development and syllabus design.

The continuous deliberate indecisiveness of education policy makers is bound to raise questions about their perception of the term 'education'. Their stereotyped view looks at education as the teaching of one or two languages and giving instruction in them. But in a multilingual nation like Kenya the minority language groups perceive education as a force for the development and revival of their languages. And therefore any strong propagation for the use of standard language or only one language for national integration and cohesion gets a mixed reaction of awe and contempt.

\section{References}

Ashcroft, B. G., 2002. The Empire Writes Back: Theory and Practice in Post-Colonial Literatures. London: Routledge.

Batibo, H., 2005. Language Decline and Language Death in Africa: Causes, Consequences And Challenges. New York: Multi Lingual Matters Ltd.

Bos, P., 2002. Serving the Nations. Retrieved December 07, 2013, http://www.servingthenations.org/nl/home

Chimerah, R. M., 1998. Kiswahili: Past, Present, and Future Horizons. Nairobi: Nairobi University Press.

Gorman, T. P., 1974. The Development of Language Policy in Kenya with Particular Reference. In W. Whiteley, Language in Kenya (pp. 390-440). Nairobi: Oxford University Press.

Jedynak, M., 2009. Critical period hypothesis revisited: The impact of age on ultimate attainment in the pronunciation of a foreign language. Frankfurt am Main: Peter Lang.

Kahraman, Ayhan, 2012. Defossilization of /æ/ phoneme pronunciation of non-native EFL treachers. Journal of Language Teaching and Research 3.3: 379-385.

Mazrui, A. A. and A. M. Mazrui, (1996. A tale of two Englishes: The imperial language in the post-colonial Kenya and Uganda. In J. C. Fishman, Post Imperial English (pp. 271-302). Berlin: Mouton de Gruyter.

Mazrui, A. A. and A. M. Mazrui, 1998. The Power of Babel: Language \& Governance in the African Experience. Oxford: J. Currey. 
Dwivedi: Linguistic Realities in Kenya

Mazrui, A. A. and A. M. Mazrui, 1999. Political Culture of Language: Swahili, Society and the State. Binghamton: Binghamton, N.Y: Institute of Global Culture Studies (IGCS), Binghamton University, the State University of New York.

Momanyi, Clara, 2009. The effects of 'Sheng' in the teaching of Kiswahili in Kenyan schools. The Journal of Pan African Studies 2.8: 127-138.

Nabea, Wendo, 2009. Language policy in Kenya: negotiation with hegemony. The Journal of Pan African Studies 3.1: 121-138.

Ngugi, G., 2011. Nimelogwa nisiwe na mpenzi. Nairobi, Kenya: East African Educational Publishers.

Ngugi, T., 1978. Homecoming. London: Heinemann.

Ogechi, N. O., 2003. On language rights in Kenya. Nordic Journal of African Studies 12.3: 277-295.

Pardoe, S., 2000. Respect and the pursuit of 'symmetry' in researching literacy and student writing. In D. H. Barton, ed., Situated Literacies-Reading andWriting in Context. (pp. 150165). London: Routledge.

Street, B., 1993. Introduction: The new literacy studies. In B. Street, ed., Cross-cultural Approaches to Literacy (pp. 1-21). Cambridge: Cambridge University Press. 